\title{
Ease of handling, physiological response, skin lesions and meat quality in pigs transported in two truck types
}

\author{
Facilidad de manipulación, respuesta fisiológica, lesiones en la piel y calidad \\ de la carne de los cerdos transportados en dos tipos de camiones
}

\author{
FA Dalla Costa ${ }^{a, b}$, MJR Paranhos da Costa ${ }^{a, b}$, L Faucitano, \\ OA Dalla Costa ${ }^{\mathrm{d}, *}$, LS Lopes ${ }^{\mathrm{d}}$, E Renuncio $^{\mathrm{e}}$
}

\begin{abstract}
A total of 1,728 pigs were transported to slaughter using two double-decked trucks, one featuring a hydraulic deck (HD) to load and unload the upper level and the other presenting a fixed upper deck (FD) only accessible by a ramp. The aim of the research was to evaluate the effects of the loading and unloading system of the truck on behaviour, blood parameters (cortisol, lactate and creatine kinase $[\mathrm{CK}])$, skin lesions and meat quality traits. The use of HD resulted in easier and faster loading $(\mathrm{P}<0.05$ for both) compared with the FD. Blood cortisol levels were influenced by the loading/unloading system, with lower $(\mathrm{P}<0.05)$ levels being found in pigs using HD transport when compared to those using FD transport. Truck type had no effect on the incidence of skin lesions and pork quality in this study $(\mathrm{P}>0.05)$. It can be concluded that the use of the truck model featuring the upper hydraulic deck should be recommended to ease of handling at loading improving animal welfare and reducing the work load of handlers.
\end{abstract}

Key words: transport, handling, blood parameters, skin damage.

RESUMEN. El objetivo del trabajo fue estudiar los efectos del sistema de carga y descarga de camiones de dos pisos en el comportamiento, parámetros fisiológicos (cortisol, lactato, creatina quinasa [CK], lesiones en la piel y la calidad de carne de los cerdos). Para ello, 1.728 cerdos fueron transportados a una planta faenadora de carnes utilizando dos camiones de dos pisos con diferentes sistemas, uno con piso hidráulico (HD) para el carga y descarga desde la planta superior, y otro con piso superior fijo (FD), accesible solo por medio de rampas de carga y descarga. El uso de HD resultó en una mayor facilidad y un menor tiempo de carga $(\mathrm{P}<0,05$ para ambos) en comparación con el FD. Los niveles de cortisol de los cerdos fueron influenciados por el sistema de carga y descarga, encontrándose los niveles más bajos $(\mathrm{P}<0,05)$ en los cerdos transportados con HD en comparación con con FD. El modelo del camión no afectó la incidencia de lesiones de la piel y la calidad de la carne de los cerdos en este estudio ( $\mathrm{P}>0,05)$. Por tanto, se puede concluir que el uso de modelos de camiones equipados con piso hidráulico puede ser recomendado para aumentar la facilidad de manipulación de los cerdos durante la carga, y por consiguiente, reducir la mano de obra de los trabajadores y mejorar el bienestar animal.

Palabras clave: transporte, manejo, parámetros sanguíneos, lesiones de piel.

\section{INTRODUCTION}

Transportation is considered as the most stressful event for pigs prior to slaughter (Geverink et al 1998) which may compromise the welfare of animals and ultimately pork quality (Warriss 1998, Von Borell and Schaffer 2005, Schwartzkopf-Genswein et al 2012). The vehicle design plays a major role contributing to the incidence of animal losses during transport (Dewey et al 2009), with higher proportion of losses being associated to the use of trucks equipped with ramps when compared to vehicle equipped with hydraulic decks (Kephart et al 2010, Correa

Accepted: 10.03.2016.

aDepartamento de Zootecnia, Universidade Estadual Paulista, Jaboticabal, Brazil.

bETCO-Grupo de Estudos e Pesquisa em Etologia e Ecologia Animal, Jaboticabal, Brazil.

${ }^{\mathrm{c}}$ Agriculture and Agri-Food Canada, Dairy and Swine R \& D Centre, Sherbrooke, Canada.

dEMBRAPA Swine and Poultry, Concórdia (SC), Brazil.

${ }^{e}$ Cooperativa Central Aurora Alimentos, Chapecó (SC), Brazil.

*Corresponding author: OA Dalla Costa; osmar.dallacosta@embrapa.br et al 2013). Research showed that loading and unloading pigs through ramps impose a strong physical exertion on pigs as showed by the higher heart rate (Correa et al 2013, Goumon et al 2013) making them hard to move in and off the vehicle and increasing the use of electric prods, all resulting in longer handling time (Torrey et al 2013). The results from comparative studies including trucks featuring ramps or hydraulic decks as regards pork quality are rather inconclusive, ranging from no effect (Correa et al 2013) to improved pork quality (Dalla Costa et al 2007, Weschenfelder et al 2013).

Due to economic reasons, the use of double and triple-decked trucks for the transport of pigs is rapidly increasing in Brazil (Dalla Costa et al 2007). However, not all truck models are equipped with hydraulic decks, and those that are not, use steep ramps $\left(>20^{\circ}\right)$ to load on and off pigs located on the upper deck. It has been shown using ramps which are too steep reduces the ease of handling and results in greater physical effort for pigs and handlers as shown by increased heart rate (Goumon et al 2013).

However, to our knowledge there are no studies on the effects of these truck models on the welfare and meat quality of pigs in Brazil. Therefore, the aim of this study was 
to compare the effects of two commercial double-decked trucks, one with fixed upper deck (FD) and the other with hydraulic upper deck (HD) on pigs' welfare, handling efficiency, and carcass and meat quality traits.

\section{MATERIAL AND METHODS}

All experimental procedures performed in this study were approved by the São Paulo State University's Animal Research Ethics Board (protocol number 6119-08).

ANIMALS, FARM FACILITIES AND HANDLING OF PIGS ON THE FARMS

A total of 1,728 crossbred pigs (BW of $115 \pm 2.3 \mathrm{~kg}$ ) were transported from nine commercial swine farms to a commercial abattoir located in Santa Catarina state (Brazil) over a distance of $78 \mathrm{~km}( \pm 13)$ average, with $70 \mathrm{~km}( \pm 9 \mathrm{~km})$ on paved road and $8 \mathrm{~km}( \pm 5 \mathrm{~km})$ on dirt road. Transport trials were run during the summer 2009 at an average ambient temperature during the transport of $17.5^{\circ} \mathrm{C}$ (range from 16 to $22^{\circ} \mathrm{C}$ ).

All farms consisted of only one finishing facility with similar design and capacity to finish 450 pigs $( \pm 25)$ per cycle (170 days). Pigs were kept in pens (10.4 \pm 0.4 pigs/ pen) on concrete floor at an average density of $1.15 \mathrm{~m}^{2} / \mathrm{pig}$.

Once the slaughter weight was achieved, pigs were fasted for $12 \mathrm{~h}$ before loading. At each farm, pigs were loaded in groups of 4 pigs each by trained handlers using paddles and rattles. Each farm had a loading ramp (10.5 $\pm 0.5 \mathrm{~m}$ long) which could be adjusted to load pigs on the bottom and the upper $\operatorname{deck}\left(15^{\circ}\right.$ and $20^{\circ}$ slope, respectively) of the truck.

\section{TRUCK DESIGN AND TRANSPORT CONDITIONS}

In this study, the two trucks and drivers were the same on each journey (9 journeys) to the slaughter plant. The trucks (Triel-HT, Erechim, Brazil) were of double-decked type either featuring a fixed or a hydraulic upper deck (FD and $\mathrm{HD}$, respectively). A technical description of both trucks is presented in table 1 . In both trucks pigs were transported for $118 \mathrm{~min}( \pm 37)$ at a density of $230 \mathrm{~kg} / \mathrm{m}^{2}$. In the FD truck pigs were distributed into 12 compartments ( 6 per deck) holding 8 pigs each, while in HD truck pigs were transported in 6 compartments ( 3 per deck) holding 16 pigs each.

\section{LOADING AND UNLOADING TIME, AND EASINESS OF HANDLING}

Loading time was recorded from the moment the first pig nose crossed the farm gate until the rear leg of the last pig crossed the truck gate. Similarly, unloading time was recorded starting from the instant the gates of the truck opened until the rear leg of the last pig crossed the truck gate.
Table 1. Technical features of the vehicles used.

Características técnicas de los vehículos usados.

\begin{tabular}{|c|c|c|}
\hline & \multicolumn{2}{|c|}{ Truck type } \\
\hline & FD & HD \\
\hline Flooring & Aluminium & Aluminium \\
\hline Roof & No & No \\
\hline Chassis & Volkswagen* & Volkswagen* \\
\hline Body closure & $\begin{array}{l}\text { Closed front } \\
\text { Open sided }\end{array}$ & $\begin{array}{l}\text { Closed front } \\
\text { Open sided }\end{array}$ \\
\hline Loading device & Ramp & Ramp \\
\hline Load capacity ( $\mathrm{n}$ of pigs) & 96 & 96 \\
\hline Loading surface $\left(\mathrm{m}^{2}\right)$ & 43.2 & 43.2 \\
\hline Loading surface/compartment $\left(\mathrm{m}^{2}\right)$ & 3.6 & 7.2 \\
\hline Number of decks & Two & Two \\
\hline Deck type & Fixed & Hydraulic \\
\hline Deck length (m) & 9 & 9 \\
\hline Deck width (m) & 2.4 & 2.4 \\
\hline Deck height (m) & 0.9 & 1.05 \\
\hline Ventilation & Natural & Natural \\
\hline Number of compartments & 12 & 6 \\
\hline Number of compartments/deck & 6 & 3 \\
\hline
\end{tabular}

*Model 24.220 (6x4) 2006.

The ease of handling at loading and unloading was scored by trained observers using a subjective scale ranging from extremely difficult (score 1) to extremely easy handling (score 5). It was based on an appraisal of the frequency of slips, falls, vocalizations, pig stopping and contacts between handler and pigs. Higher scores meant a lower number of slips, falls, vocalizations, pig stopping and contacts between handler and pigs which was considered better than low scores. Slips and falls were defined as when one leg of a pig splits away from the other opposite leg or when a pig falls down (at least 2 legs buckled under) with some part of the body physically touching the floor; vocalizations were any squeals produced by the pigs and did not include grunts; pig stopping was when a pig stops for more than approximately 2 seconds; and contact between the handler and pigs was any contact when the handler used his voice or touched the pigs by hand, paddle or board to encourage forward movement of 1 or the group of pigs.

\section{HANDLING OF PIGS IN THE SLAUGHTERHOUSE}

On arrival at the slaughterhouse, pigs were unloaded with an adjustable-slope metal ramp (5 $\mathrm{m}$ length) with anti-skid floor. To reach the FD the ramp slope was adjusted to $10^{\circ}$ slope, while for unloading pigs from HD the ramp was kept level. In the lairage, pigs from different trucks were kept in separate pens (no mixing). After $6 \mathrm{~h}$ lairage, pigs were driven to slaughter using a paddle, boards and rattles, electrically stunned (head-to-chest electrical stunning) and 
exsanguinated in the horizontal position. After slaughter, carcasses were eviscerated, split, and chilled according to standard commercial practices and kept in the cooler at $1-4{ }^{\circ} \mathrm{C}$ for $24 \mathrm{~h}$ pending cold deboning.

\section{PHYSIOLOGICAL MEASUREMENTS}

Blood samples $(10 \mathrm{~mL})$ were collected from 432 pigs using vacuum tubes (Vacuplast, Cral Artigos para Laboratório Ltd., São Paulo, Brazil) from sentinel pigs (2/compartment in the FD truck and 4/compartment in the HD truck for each journey), in order to extract serum for creatine kinase (CK) and cortisol analysis. Another 2 $\mathrm{mL}$ of blood was collected in a tube containing $3.0 \mathrm{mg}$ of sodium fluoride and $6.0 \mathrm{mg}$ of $\mathrm{Na}_{2}$ EDTA solution to extract plasma for lactate analysis. Samples were immediately centrifuged at $4{ }^{\circ} \mathrm{C}$ for $12 \mathrm{~min}$ at $1,400 \mathrm{~g}$. Plasma was transferred into $1.5 \mathrm{~mL}$ Eppendorf tubes and stored at $-80^{\circ} \mathrm{C}$ until lactate determination. Serum samples were kept at room temperature $\left(\sim 23^{\circ} \mathrm{C}\right)$ for $1 \mathrm{~h}$ before refrigeration at $4{ }^{\circ} \mathrm{C}$. The following day, serum samples were centrifuged at $4{ }^{\circ} \mathrm{C}$ for $12 \mathrm{~min}$ at $1.400 \mathrm{~g}$, transferred into $1.5 \mathrm{~mL}$ Eppendorf tubes and stored at $-80{ }^{\circ} \mathrm{C}$ until analysis. Lactate levels were measured using a commercially available kit (Lactat PAP enzyme Farbtest, Rolf Greiner Biochemica, Flacht, Germany) and CK levels were determined with creatine kinase-kit (CK-NAK FS, Diasys-Diagnostic Systems Internacional, Holzheim, Germany). Plasma lactate concentrations were determined with a microplate reader and serum CK concentrations were determined with a spectrophotometer. The quantitative determination of cortisol was made using a commercial kit (Coat-A-Count Cortisol Kit, Diagnostic Products Corporation, Los Angeles, CA) with a microplate reader and expressed in $\mathrm{ng} / \mathrm{mL}$. The intra-assay CV was $28.3,34.3$ and $45.2 \%$ for CK, lactate and cortisol, respectively.

\section{SKIN LESIONS}

Skin lesions were evaluated in a total of 432 pigs, and the same pigs were used for physiological measurements. The number of skin lesions was counted on the left side of the body of the same pigs evaluated in each phase of preslaughter handling, such as at the farm (one day before loading), at unloading and in the lairage pen, and the percentage of pigs showing lesions was calculated.

In the cooler, on each left carcass side skin lesions were classified as fighting type lesions ( $1=$ less than 10 lesions; $2=11$ to 20 lesions; and $3=$ greater than 20 lesions) or mounting (score $1=$ less than 5 lesions; $2=6$ to 10 lesions; and $3=$ greater than 10 lesions) by visual assessment of shape and size according to the photographic standards of the Institut Technique du Porc (ITP, 1996) as described by Faucitano (2001). According to the ITP scale, lesions due to biting during fighting are 5 to $10 \mathrm{~cm}$ in length, comma shaped, and mostly concentrated in the anterior (head and shoulders) and posterior (ham) regions of the carcass. Long (10 to $15 \mathrm{~cm})$, thin $(0.5-$ to $1-\mathrm{cm}$-wide), comma shaped lesions densely concentrated on the back of pigs caused by the fore claws were classified as mounting type lesions (Correa et al 2014).

\section{MEAT QUALITY}

Meat quality was measured in 432 carcasses of the same pigs used for carcass evaluation. Muscle $\mathrm{pH}$ was assessed at $45 \mathrm{~min}\left(\mathrm{pH}_{\mathrm{i}}\right)$ and $24 \mathrm{~h}\left(\mathrm{pH}_{\mathrm{u}}\right)$ post-mortem using a pHmeter (HI 8314 model, Hanna Instruments, São Paulo, Brazil) fitted with a spear type electrode (HI 1217D, Hanna Instruments, São Paulo, Brazil) and an automatic temperature compensation probe (Tec 530, Hanna Instruments, São Paulo, Brazil) by insertion into the Longissimus dorsi ( $\mathrm{LD}$; between the $13^{\text {th }}$ and $\left.14^{\text {th }} \mathrm{rib}\right)$ and Semimembranosus (SM) muscles.

Instrumental colour ( $\mathrm{L}^{*}, \mathrm{a}^{*}$ and $\mathrm{b}^{*}$ values) of the $\mathrm{LD}$ and SM muscles was evaluated $24 \mathrm{~h}$ after slaughter with a Minolta Chromameter (CR-400; Minolta Camera Ltd., Osaka, Japan) equipped with a $25 \mathrm{~mm}$ aperture, $0^{\circ}$ viewing angle, and D65 illuminant. Visual color was evaluated using the NPPC Pork Quality Standards (National Pork Producers Council, 1999). Drip loss was measured in the LD and SM muscles using a modified EZ-driploss method (Correa et al 2007). Briefly, two $25 \mathrm{~mm}$ diameter muscle cores were removed from the center of $2.5 \mathrm{~cm}$ thick LD (removed at $13^{\text {th }} / 14^{\text {th }}$ last rib) and SM muscle chops, weighed and placed into plastic drip loss containers (KABE Labortechnik, Umbrecht-Elsenroth, Germany) at $24 \mathrm{~h}$ post-mortem and stored for $48 \mathrm{~h}$ at $4{ }^{\circ} \mathrm{C}$. At the end of the $48 \mathrm{~h}$ storage period, muscle cores were removed from their containers, surface moisture was carefully dabbed, cores were reweighed, and drip loss percentage was calculated by dividing the difference between initial and final core weights by the initial core weight.

To assess cooking losses, four LD muscle chops $(150 \mathrm{~g}$ ) were vacuum-packed in heat resistant sealed plastic bags and cooked in water bath at $80^{\circ} \mathrm{C}$ for $1 \mathrm{~h}$. Chops were then placed on absorbent paper to remove surface moisture and weighed when the internal temperature reached $20-25^{\circ} \mathrm{C}$. The weight loss was calculated by difference between initial and final weight (Honikel 1998). The same LD muscle chops were then cooled at $0{ }^{\circ} \mathrm{C}$ for $12 \mathrm{~h}$ and used for the determination of Warner-Bratzler shear force. Five rectangular cores $(1 \times 1 \times 2 \mathrm{~cm})$, parallel to the longitudinal orientation of the muscle fibers, were taken in each chop and analysed using a Warner-Bratzler device attached to a TAXT2i Texture Analyzer (Stable Micro Systems, Survey, UK). The meat quality classification was calculated according to quality criteria set for this study (table 2, based on Flores et al 1999 and Faucitano et al 2010). 
Table 2. Meat quality classification according to $\mathrm{pH}_{\mathrm{u}}$ and colour ( $\mathrm{L}^{*}$ value).

Clasificación de la calidad de la carne de acuerdo a $\mathrm{pH}_{u}$ y color (valor de $\mathrm{L}^{*}$ ).

\begin{tabular}{lccc}
\hline Classes $^{1}$ & $\mathrm{pH}_{\mathrm{u}}$ & Driploss & $\mathrm{L}^{*}$ \\
\hline PSE & $<6.0$ & $>6.0$ & $>50$ \\
RSE & $<6.0$ & $>6.0$ & $45-50$ \\
PFN & $<6.0$ & $<6.0$ & $>50$ \\
RFN & $5.5-6.1$ & $<6.0$ & $<50$ \\
DFD & $\geq 6.1$ & $<3.0$ & $<44$ \\
\hline
\end{tabular}

${ }^{1}$ PSE: pale, soft and exudative; RSE: red, soft and exudative; PFN: Pale, Firm, non-exudative; RFN: red, firm and non-exudative; DFD: dark, firm and dry.

\section{STATISTICAL ANALYSIS}

Variance analysis using GLM SAS (2003) was applied to study the effects of truck type on quantitative variables, such as cortisol, lactate, $\mathrm{CK}, \mathrm{pH}$, color, drip loss and cooking losses, with the group as experimental unit for the analysis of easiness of handling data and the individual as the experimental unit for the analysis of physiological and meat quality data. The likelihood ratio and chi-square tests were used to compare the easiness of handling, skin lesion-type categories and meat quality classification. The two tests were performed using the FREQ procedure of SAS (2003).

\section{RESULTS AND DISCUSSION}

\section{LOADING AND UNLOADING TIME, AND EASINESS OF HANDLING}

The use of HD shortened the time to loading and unloading the truck $(44 \pm 5$ and $15 \pm 2$ min, respectively; $\mathrm{P}<0.05)$ compared with FD $(50 \pm 11$ and $19 \pm 3$ min, respectively; $\mathrm{P}$ $<0.05)$. The shorter loading and unloading time in the HD truck may be explained by the easier handling at loading and unloading (scores $=4.0$ and 3.4, respectively; $\mathrm{P}<$ 0.05 ) compared with the FD truck (scores $=1.5$ and 1.3 , respectively; $\mathrm{P}<0.05)$. These results are not surprising as they confirm the significant improvement in the easiness of loading and unloading pigs when hydraulic systems are used instead of sloped ramps (Brown et al 2005, Torrey et al 2013, Weschenfelder et al 2012, 2013, Garcia and McGlone 2015). The aforementioned observations are relevant to the performance of pre-slaughter phase because an increase in loading and unloading times, associated with handling difficulties, may prompt exhaustion of handler team and lead to losses in manpower quality.

\section{PHYSIOLOGICAL RESPONSE}

Except for blood cortisol levels, truck type had no effect on the other blood stress parameters assessed in this study ( $\mathrm{P}>0.05$; table 3$)$. Pigs transported on the HD truck showed lower $(\mathrm{P}<0.05)$ blood cortisol levels than those located on the FD truck. Reduced exsanguination blood cortisol levels in pigs handled using hydraulic systems compared with ramps were previously reported by Ludtke et al (2012) and Weschenfelder et al (2012) and would indicate that incomplete recovery from the psychological stress of negotiating a ramp in FD pigs.

During preslaughter handling, salivary cortisol levels can treble and they do not recover to their initial levels until 3 hours of lairage (Dalla Costa et al 2008), confirming that this hormone can be considered a relatively long-term stress response (Weschenfelder et al 2013). The blood lactate usually returns to basal levels within $2 \mathrm{~h}$ after physical exercise (Correa et al 2013), but in the present study stress was continuous up to the time of slaughter and this may explain the lack of treatment effect in this variable. Nevertheless, the blood lactate levels at exsanguination were greater than $4 \mathrm{mM}$ in both treatments, which is the resting level of blood lactate for market-weight pigs (Edwards et al 2011). This reflects a general state of fatigue in pigs transported by both truck types. On the other side, the CK level achieves a peak within 6 hours after physical stress and does not return to basal level until 48 hours (Correa et al 2013), implying that the physical stress of climbing the ramp was not intense enough to create a treatment difference.

The evidence that the effects of the ramp were more psychological than physical in this study is provided by the lack of effect of truck type on the variation in exsanguination blood lactate and CK level, both indicators of physical stress. Ludtke et al (2012) also failed to report variation in blood lactate and CK levels in pigs transported in similar Brazilian truck types.

\section{SKIN LESIONS}

As previously reported by Dalla Costa et al (2007, 2009), in this study the incidence of pigs presenting skin lesions increased from farm $(32.3 \%)$ to slaughter $(96.6 \%)$ with loading, transportation and unloading

Table 3. Effect of truck type (FD or fixed deck vs. HD or hydraulic deck) on blood stress indicators ${ }^{1}$.

Efecto del tipo de camión (FD o piso superior fijo vs. HD o piso hidráulico) en indicadores ${ }^{1}$ sanguíneos de estrés.

\begin{tabular}{lcc}
\hline \multirow{2}{*}{ Parameters } & \multicolumn{2}{c}{ Truck Type } \\
\cline { 2 - 3 } & FD & HD \\
\hline CK $(\log \mathrm{UI} / \mathrm{L})^{2}$ & $5.82 \pm 0.22$ & $6.35 \pm 0.26$ \\
Lactate $(\mathrm{mN})$ & $14.92 \pm 0.52$ & $14.92 \pm 0.49$ \\
Cortisol $(\mu \mathrm{g} / \mathrm{dL})$ & $7.67 \pm 0.42^{\mathrm{a}}$ & $6.29 \pm 0.30^{\mathrm{b}}$ \\
\hline
\end{tabular}

${ }^{1}$ Mean values and standard deviation.

${ }^{2} \mathrm{CK}$ : Creatine kinase.

${ }^{\mathrm{a}, \mathrm{b}}$ Means lacking a common superscript differ $(\mathrm{P}<0.05)$. 
being responsible for $36.2 \%$ of the increase while $28 \%$ was caused by lairage.

However, similarly to previous studies (Nanni Costa et al 1999, Weschenfelder et al 2012, 2013, Correa et al 2013), in this study loading and unloading pigs using an hydraulic system did not influence skin lesions in neither live pigs nor carcasses $(P>0.05$; table 4$)$. Since a higher number of pigs in one compartment increases the probability of contacts between pigs, there could be an effect of truck type on the incidence of pigs with skin lesions at unloading and on the number of carcass lesions. However, when the density is within the guidelines of the EU, the group size effect is not significant. These results may indicate that when pigs are handled gently in small groups using proper handling tools, the impact of loading/unloading equipment in the truck on skin lesions is not important.

\section{MEAT QUALITY TRAITS}

Except for Minolta colour a* (meat redness) assessed in the SM muscle, truck type had no effect on the meat quality parameters evaluated in this study. A greater $(\mathrm{P}$ $<0.05)$ Minolta a* value was recorded in SM muscle of HD pigs (table 5). The distribution of meat quality classes (PSE, PFN, RSE, RFN, DFD) was not affected (P < 0.05 ; table 6 ) by the treatments. However, this result is not economically important as the $a^{*}$ value is still within the range of normal meat quality. Other studies also failed to find effects of hydraulic $v s$. ramp use at loading and unloading on meat quality traits (Dalla Costa et al 2007, Ludtke et al 2012, Weschenfelder et al 2012). The distribution shown in table 6 is in agreement with Araujo (2009) who evaluated the meat quality in pig abattoirs in Brazil. The RFN is the most desirable meat for the pork chain, and had the highest incidence in both studies. On the other side, the studies found a low incidence of PSE

Table 4. Effect of truck type (FD or fixed deck vs. HD or hydraulic deck) on the number of skin lesion in pigs ${ }^{1}$.

Efecto del tipo de camión (FD o piso superior fijo vs. HD o piso hidráulico) en el número de lesiones en la piel de los cerdos ${ }^{1}$.

\begin{tabular}{lccc}
\hline & Variable & \multicolumn{2}{c}{ Truck Type } \\
\cline { 3 - 4 } & & FD & HD \\
\hline \multirow{2}{*}{$\begin{array}{l}\text { Skin lesions on } \\
\text { the body, n }\end{array}$} & Loading & $0.71 \pm 0.08$ & $0.51 \pm 0.06$ \\
& Unloading & $1.51 \pm 0.11$ & $1.28 \pm 0.10$ \\
Skin lesions on & & $3.56 \pm 0.17$ & $3.22 \pm 0.17$ \\
the carcass, n & & $15.14 \pm 0.58$ & $13.53 \pm 0.66$ \\
& & & \\
Skin le- & Fighting & $5.95 \pm 0.46$ & $4.99 \pm 0.54$ \\
sion-type on & Density & $1.86 \pm 0.09$ & $1.98 \pm 0.11$ \\
carcass, n & Handling & $7.32 \pm 0.35$ & $6.55 \pm 0.33$ \\
\hline
\end{tabular}

${ }^{1}$ Mean values and standard deviation.
Table 5. Effect of truck type (FD or fixed deck vs. HD or hydraulic deck) on meat quality parameters as assessed in the Longissimus dorsi (LD) and Semimenbranosus (SM) muscles ${ }^{1}$.

Efecto del tipo de camión (FD o piso superior fijo vs. HD o piso hidráulico) sobre los parámetros de calidad de carne según la evaluación en el músculos Longissimus dorsi (LD) y Semimenbranosus (SM).

\begin{tabular}{|c|c|c|}
\hline \multirow{2}{*}{ Parameters } & \multicolumn{2}{|c|}{ Truck Type } \\
\hline & FD & $\mathrm{HD}$ \\
\hline \multicolumn{3}{|l|}{ LD muscle } \\
\hline $\mathrm{pH}_{1}$ & $6.21 \pm 0.01$ & $6.23 \pm 0.02$ \\
\hline $\mathrm{pH}_{\mathrm{U}}$ & $5.60 \pm 0.01$ & $5.61 \pm 0.00$ \\
\hline $\mathrm{L}^{*}$ & $45.22 \pm 0.17$ & $44.96 \pm 0.19$ \\
\hline$a^{*}$ & $5.75 \pm 0.08$ & $5.78 \pm 0.09$ \\
\hline$b^{*}$ & $-1.12 \pm 0.14$ & $-0.79 \pm 0.12$ \\
\hline NPPC Colour Scale & $2.98 \pm 0.05$ & $3.11 \pm 0.05$ \\
\hline Drip loss (\%) & $3.87 \pm 0.13$ & $3.78 \pm 0.15$ \\
\hline Shear force $(\mathrm{Kg})$ & $5.91 \pm 0.12$ & $5.85 \pm 0.11$ \\
\hline \multicolumn{3}{|l|}{ SM muscle } \\
\hline $\mathrm{pH}_{1}$ & $6.28 \pm 0.02$ & $6.25 \pm 0.01$ \\
\hline $\mathrm{pH}_{\mathrm{U}}$ & $5.61 \pm 0.01$ & $5.62 \pm 0.01$ \\
\hline $\mathrm{L}^{*}$ & $45.85 \pm 0.18$ & $45.77 \pm 0.17$ \\
\hline$a^{*}$ & $6.91 \pm 0.09^{\mathrm{a}}$ & $6.60 \pm 0.09^{\mathrm{b}}$ \\
\hline$b^{*}$ & $-0.50 \pm 0.14$ & $-0.37 \pm 0.12$ \\
\hline NPPC Colour Scale & $3.14 \pm 0.04$ & $3.16 \pm 0.05$ \\
\hline Drip loss $(\%)$ & $2.97 \pm 0.13$ & $2.88 \pm 0.12$ \\
\hline
\end{tabular}

${ }^{1}$ Mean values and standard deviation.

a,b Means lacking a common superscript differ $(\mathrm{P}<0.05)$.

${ }^{\mathrm{c}}$ Based on NPPC colour standards from 1 (pale) to 6 (dark) (NPPC 1999).

Table 6. Meat quality classification ${ }^{1}$ according to effect of truck type (FD or fixed deck vs. HD or hydraulic deck) as assessed in the Longissimus dorsi (LD) and Semimenbranosus (SM) muscles ${ }^{2}$.

Clasificación ${ }^{1}$ de la calidad de carne de acuerdo con efecto del tipo de camión (FD o piso superior fijo vs. HD o piso hidráulico) evaluados en el músculos ${ }^{2}$ Longissimus dorsi (LD) y Semimenbranosus (SM).

\begin{tabular}{lccc}
\hline \multirow{2}{*}{ Classes $^{3}$} & \multicolumn{2}{c}{ Truck Type } \\
\cline { 3 - 4 } & & FD (\%) & HD (\%) \\
\hline LD muscle & & & \\
& PFN & 1.9 & 3.6 \\
& PSE & 2.5 & 1.8 \\
& RFN & 80.5 & 77.2 \\
SM muscle & RSE & 15.1 & 17.4 \\
& DFD & - & - \\
& & & \\
& PFN & 4.3 & 8.3 \\
& PSE & 1.2 & 0 \\
& RFN & 89.0 & 84.6 \\
& RSE & 5.5 & 7.1 \\
& DFD & - & - \\
\hline
\end{tabular}

\footnotetext{
${ }^{1}$ See Material and methods (table 2) for more details.

${ }^{2}$ Percentage of $L D$ and $S M$ muscles classified in each treatment.

${ }^{3}$ PSE: pale, soft and exudative; RSE: red, soft and exudative; PFN: Pale, Firm, non-exudative; RFN: red, firm and non-exudative; DFD: dark, firm and dry.
} 
defect in pork. As with the study by Araujo (2009) in which the conditions were very similar to this study, the frequency of DFD defect was very low.

It is possible to conclude that the use of the hydraulic deck in the truck to load and unload pigs improves the efficiency of transport in terms of time and easiness. However, it is suggested that when pigs are well handled in these phases the impact of the vehicle design on skin lesions and meat quality variation is minimal.

\section{ACKNOWLEDGEMENTS}

The authors appreciate the assistance of L. C Ajala, E. L. Klein and D. da Silva, for the data collection at the slaughter plant and laboratory analysis. Sincere thanks go to the CNPQ (National Council of Technological and Scientific Development) for granting a Master scholarship to Filipe Dalla Costa. The authors are grateful to Swine and Poultry Research Centre of Embrapa for the financial support and to Cooperativa Central Aurora Alimentos and Cooperativa Regional Itaipu for the financial support, manpower, and facilities usage.

\section{REFERENCES}

Araújo AP. 2009. Manejo pré-abate e bem-estar dos suínos em frigoríficos brasileiros. Tesis Doctoral, Faculdade de Medicina Veterinária e Zootecnia, Universidade Estadual Paulista, Botucatu, Brazil.

Brown SN, TG Knowles, LJ Wilkins, SA Chadd, PD Warriss. 2005. The response of pigs to being loaded or unloaded onto commercial animal transporters using three systems. Vet J 170, 91-100.

Correa JA, S Méthot, L Faucitano. 2007. A modified meat juice container (ez-driploss) procedure for a more reliable assessment of drip loss and related quality changes in pork meat. J Muscle Foods 18, 67-77.

Correa JA, S Torrey, N Devillers, JP Laforest, HW Gonyou, L Faucitano. 2010. Effects of different moving devices at loading on stress response and meat quality in pigs. J Anim Sci 88, 4086-4093.

Correa JA, HW Gonyou, S Torrey, T Widowski, R Bergeron, TG Crowe, JP Laforest, L Faucitano. 2013. Welfare and carcass and meat quality of pigs being transported for 2 hours using two vehicle types during two seasons of the year. Can J Anim Sci 93, 43-55.

Dalla Costa OA, L Faucitano, A Coldebella, JV Ludke, JV Peloso, D Dalla Roza, MJR Paranhos da Costa. 2007. Effects of the season of the year, truck type and location on truck on skin lesions and meat quality in pigs. Livest Prod Sci 107, 29-36.

Dalla Costa OA, JV Ludke, MJR Paranhos da Costa, L Faucitano, A Coldebella, JD Kich, JV Peloso, D Dalla Roza. 2008. Tempo de jejum na granja sobre o perfil hormonal e os parâmetros fisiológicos em suínos de abate pesados. Ciênc Rural 38, 2300-2306.

Dalla Costa OA, JV Ludke, MJRP Paranhos da Costa, L Faucitano, JV Peloso, D Dalla Roza, A Coldebella. 2009. Efeito do jejum na granja e condições de transporte sobre o comportamento dos suínos de abate nas baias de descanso e lesões na pele. Ciênc Anim Bras 10, 48-58.

Dewey C, C Haley, T Widowski, Z Poljak, R Friendship. 2009. Factors associated with in-transit losses of fattening pigs. Anim Welfare $18,355-361$.
Edwards LN, T Grandin, TE Engle, SP Porter, MJ Ritter, AA Sosnicki, DB Anderson. 2010. Use of exsanguination blood lactate to assess the quality of pre-slaughter pig handling, Meat Sci 86, 384-390.

Faucitano L. 2001. Causes of skin damage to pig carcasses. Can J Anim Sci 81, 39-45.

Faucitano L, MC Ielo, C Ster, DP Lo Fiego, S Methot, L Saucier. 2010. Shelf life of pork from five different quality classes. Meat Sci 84, 466-469.

Flores M, E Armero, MC Aristoy, F Toldrà. 1999. Sensory characteristics of cooked pork loin as affected by nucleotide content and post-mortem meat quality. Meat Sci 51, 53-59.

Garcia A, J McGlone. 2015. Loading and unloading finishing pigs: effects of bedding types, ramp angle, and bedding moisture. Animals 5, 13-26.

Geverink A, A Buhnemann, JA Van de Burgwal, E Lambooij, HJ Blokhuis, VM Wiegant. 1998. Responses of slaughter pigs to transport and lairage sounds. Physio Behav 63, 667-673.

Goumon S, L Faucitano, R Bergeron. 2013. Effect of ramp configuration on easiness of handling, heart rate and behavior of near-market pigs at unloading. J Anim Sci 91, 3889-3898.

Honikel KO. 1998. Reference methods for the assessment of physical characteristics of meat. Meat Sci, 49, 447-457.

ITP, Institut Technique du Porc. 1996. Notation des hématomes sur couenne: porcs vivant ou carcasses. ITP, Rennes, France.

Kephart KB, MT Harper, CR Raines. 2010. Observations of market pigs following transport to a packing plant. J Anim Sci 88, 2199-2203.

Ludtke BC, OA Dalla Costa, RO Roça, ETF de Silveira. 2012. Bem-estar animal no manejo pré-abate e a influência na qualidade da carne suína e nos parâmetros fisilógicos do estresse. Ciênc Rural 42, 532-537.

Nanni Costa L, DP Lo-Fiego, S Dall'-Olio. 1999. Influence of loading method and stocking density during transport on meat and dry-cured ham quality in pigs with different halothane genotypes. Meat Sci 51, 391-399.

NPPC, National Pork Producers Council. 1999. Color measurement on pork carcasses. Color Quality Meeting. Iowa State University, Ames, IA, USA.

SAS, Statistical Analysis System Institute. 2003. System for Microsoft windows, release 9.1. Cary, USA.

Schwartzkopf-Genswein KSG, L Faucitano, S Dadgar, P Shand, LA González, TG Crowe. 2012. Meat Sci 92, 227-243.

Torrey S, R Bergeron, TN, TJAJ Brown, HW Gonyou, L Faucitano. 2013. Transportation of market- weight pigs: I. Effect of season and truck type on behavior with a $2 \mathrm{~h}$ transport. J Anim Sci 91, 2863-2871.

Von Borell E, D Schaffer. 2005. Legal requirements and assessment of stress and welfare during transportation and pre-slaughter handling of pigs. Livest Prod Sci 97, 81-87.

Warriss PD. 1998. The welfare of slaughter pigs during transport. Anim Welfare 7, 365-381.

Weschenfelder AV, S Torrey, N Devillers, T Crowe, A Bassols, Y Saco, M Piñeiro, L Saucier, L Faucitano. 2012. Effects of trailer design on animal welfare parameters and carcass and meat quality of three Pietrain crosses being transported over a long distance. J Anim Sci 90, 3220-3231.

Weschenfelder AV, S Torrey, N Devillers, TYM Piñeiro. 2013. Effects of trailer design on animal welfare parameters and carcass and meat quality of three Pietrain crosses being transported over a short distance. Livest Sci 157, 234-244. 